\title{
Public Health Information Behavior at Flood-Prone Area In Bandung Regency: A Case Study in Baleendah Village, Andir Village, Bojongsoang Village and Dayeuh Kolot Village
}

\author{
Nuning Kurniasih ${ }^{1}$, Sukaesih \\ Department of Library and Information Science, Faculty of Communication Science, \\ Universitas Padjadjaran
}

\begin{abstract}
This study aims to understand the public health information behavior in the vicinity of flood prone area by examining 1) The public health information behavior in identifying diseases that may occur because of a flood. 2) The information behavior in finding health information solution required for dealing with diseases that may occur because of a flood. 3) The public health information behavior in determining health information sources which is used. 4) The public health information behavior in making use of health information for diseases that may occur because of a flood. 5) The public health information behavior in making use of health institution to satisfy its information needs. 6) The public health information behavior in flood prone area. The method used in this research is qualitative method supported by Case Study approach. In this research, we analyze data obtained from Focus Group Discussion (FGD) conducted by 11 informants and in-depth interview with 20 interviewees that are competent with this research research for triangulation. The result of this research reveals that people living in the flood prone area vicinity in Baleendah Village, Andir Village, Dayeuh Kolot Village and Bojongsoang Village, Bandung Regency (1) identify the potential of a flood disease based on their experience and identification during a flood (2) search for health information solution required for overcoming disease potential because of a flood by asking directly to a doctor or health center staff or volunteers during a flood. For psychological problem, usually people consult with religious leader, although Social Agency provice service to overcome this problem. (3) The main information source used is one that is informed by the health center or village midwife. (4) People use health information to help healing process when they get sick during the disaster. Health information obtained when a flood does not happen is only for adding insights. (5) Health Agency through health center and village midwife are actively involved to give health counseling to the public on various occasions. Those five things influence The public health information behavior in the flood prone area.
\end{abstract}

Keywords: public health information behavior, disaster

Bandung is a capital city of West Java Province, a city that is geographically surrounded by mountains so it looks like a basin or a large bowl. Bandung is undoubtedly a beautiful city, of which Bandung possesses a nickname "Paris van Java". However, according

1 Korespondensi: Nuning Kurniasih. Afiliasi: Department of Library and Information Science, Faculty of Communication Science, Universitas Padjadjaran. Alamat: Jl. Raya Bandung Sumedang KM 21, Jatinangor 45363. Telepon: (022) 7796954. Email: nuning.kurniasih@unpad.ac.id 
to Kamalia Purbani, Secretary of Regional Body for Planning and Development (BAPPEDA) of Bandung City on the Work Meeting of Bandung City Readiness to Encounter Earthquake Threats, Wednesday (25/5/2011) said: "73,5\% Bandung City area is developed region. At last, if we do not handle it properly with environmental basis, it will trigger various disasters" (Budiana 2011).

Disasters can occur anywhere either occasionally or regularly due to certain conditions so it is considered as a disaster-prone area. An area regarded as a disaster-prone area is an area that has a geological, biological, hydrological, climatological, geographical, social, cultural, political, economic and technological condition or characteristic which could decrease its ability to prevent, mitigate, respond, and be ready to a certain disaste (Bupati Bandung 2013).

In addition to the disaster potential, Rovicky Dwi Putrohari, geological observer from Indonesian Geologist Association, said that because geologically Bandung is shaped like basin, it makes rainwater or water flow easily assembled, and when it gathers, the water is hardly receded. It makes Bandung into flood-prone area (MP 2014).

In 2015 up to this May, it is recorded that floods has occurred in several areas in Bandung Regency, such as in Baleendah, Kopo, Rancaekek and Banjaran areas. Each disaster brings risk, like a potential loss caused by disaster in a region within a certain time that can be formed as mortality, injury, illness, insecurity, threatened feeling, insecurity, evacuation, possession damage or loss, and disruption of social activity (Bupati Bandung 2013).

Similarly, a flood of course impacts on various aspects, including health. A flood usually contains impurities and germs. Some must-be-anticipated diseases are for example diarrhea, dengue, leptospirosis, respiratory tract infection, skin disease, gastrointestinal disease and worsening of chronic disease. From this number of diseases, according to Chief of Health Department of Bandung Regency namely Achmad Kustijadi, there are six diseases that are currently complained by the flood victim in Bandung Regency, such as aches, skin diseases, respiratory infection, stomach disorder, hypertension/high blood pressure and headache (Susanti 2014).

Potential disease mitigation in a flood-prone area should include anticipative action and responsive action during and after the disaster. Anticipatory action is intended to reduce the risk of disease caused by the disaster or on the Decree No. 24 of 2007 about Disaster Mitigation the term 'mitigation' is used. On the Decree No. 24 of 2007, mitigation is defined as a series of effort to reduce disaster risks, not only by infrastructure development but also from increasing the awareness and the ability to deal with disaster threats (Presiden RI 2007).

When a flood occurs, often transportation access is hampered. Transportation access among regions is frequently cut off, making it difficult for the disaster to be managed. Therefore the people need to be aware to understand the potential disease caused by a flood. Also, the healthcare workers should understand how health information seeking behavior of the people to anticipate the diseases caused by a flood. Given this common understanding, the people will be more ready to face a flood disaster and the healthcare workers can complete their responsibilities optimally by seeking the public behavior tendency on information seeking regarding the possibility of diseases, particularly in evacuation region. Related to information seeking behavior, the people affected by a flood need a reachable information access. This issue is also written in Ministerial Decree No. 1 of 2013 which says: The provision of accessibility is a service provided indirectly to the disaster victim and/or the people who live in a disaster prone area whether it is before, during or after the disaster in a 
form of reference, partnership network, facility and information provision (Menteri Sosial Republik Indonesia 2013).

The research we will carry out tends to see how health information behavior works particularly on the people who live in a flood-prone area. By understanding the pattern of health information behavior in a flood-prone area, we hope that this research can provide input for healthcare workers in completing their programs including health campaign for the local society. Hence the people will get proper anticipative and responsive actions and reduce the risk of anticipated illness.

Based on the presented background, the problem in this research can be formulated as follows: "How does the public health information behavior in flood-prone area in Bandung Regency work?"

This research aims to comprehend the public health information behavior in flood-prone area in Bandung Regency by thoroughly investigating on: 1). Public information behavior in identifying diseases that may occur because of a flood. 2). Public Information behavior in seeking health information solution required to overcoming disease that may occur because of a flood. 3). Public information behavior in selecting the health information sources used. 4). Public information behavior in making use of health information for diseases that may occur because of a flood. 5). Public information behavior in making use of health institution to satisfy their health information needs. 6). Health information behavior in flood-prone area.

Information behavior is a whole human behavior related to the sources or channels of information. On the other hand, information seeking behavior according to Wilson is intentional information seeking as a consequence of information needs fulfillment. On the journey of information seeking, individuals may interact with manual system (like newspaper or library), or computer-based system (like World Wide Web) (Wilson, Human Information Behavior 2000). To draw and analyze information behavior, there are several theoretical frameworks that can be applied. Yung-Hsiu Lin, Rong-rong Chen and Her-Kun Chang integrate theoretical frameworks established by Bsytrom and Hansen (2005), Wilson (2005), Sprink (2010) on a service context (Shostack, 1987) by this below model:

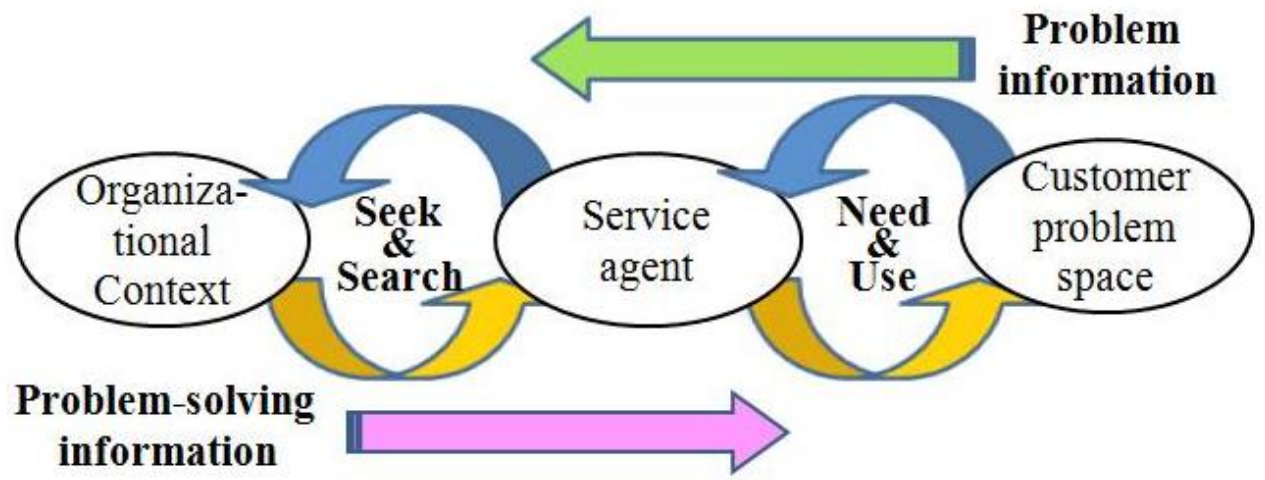

Figure 1. Information Behavior in Services Context (Lin, Chen, \& Chang, vol. 17 no. 2, June 2012)

From the Figure 1, we can see that there are three elements related to information behavior such as: 1). Service agent, 2). Problem encountered by the client, 3). Organization context. These three elements closely relate with the information behavior activity containing 
information need, external information source seeking, existing knowledge seeking and application, Spink, 2000 on (Lin, Chen and Chang vol. 17 no. 2, June 2012).

One's information behavior is different with another depends on the problem faced and how a person interact with the available information sources. Information agent in this case must be able to identify what kind of information needed to trigger the use of information to solve a problem (Dervin 1992; Kuhlthau 2004 on (Lin, Chen and Chang vol. 17 no. 2, June 2012). Information needs may the first motivation for the information agent to appropriate seek information sources on organization context and synthesize the problem-solving information with her base knowledge (Sonnenwald 1999) on (Lin, Chen and Chang vol. 17 no. 2, June 2012).

\section{Method}

The method used in this research is qualitative method supported by Case Study approach. In this research, we analyze data obtained from Focus Group Discussion (FGD) conducted by informants and in-depth interview with sources that are competent with this research theme. Informants in this study are selected based on several criteria, such as a person who: 1) owns a permanent residence in the prone flood area in Bandung Regency. 2) has experienced as a flood victim in Bandung Regency area. 3) has been infected by disease because of a flood. 4) has never been infected disease because of a flood. 5) has lived in evacuee camp with 20 people. In addition to that, triangulation is conducted with a source from Health Department of Bandung Regency (1 person), Social Department (1 person), Regional Disaster Management Agency/ BPBD (1 person), community health center (4 persons) and village apparatus (4 persons). The total of the respondent is 11 persons.

\section{Result}

\section{Flood Disaster in Bandung Regency}

As has been discussed in the previous section, the four regions that become the subject of this research are regions that regularly flooded, such as Baleendah Village, Andir Village, Dayeuh Kolot Village and Bojongloa Village. Floods regularly affect these regions because they are the meeting point of Citarum River and Cisangkuy River. From these four regions, Andir Village and Dayeuh Kolot regions become the most damaged area affected by a flood. In addition to the disadvantage of geographical position, floods in Bandung Regency are also caused by deficient city plan and the people's littering behavior.

\section{Flood Disaster Mitigation in Bandung Regency}

According to Regional Decree of Bandung Regency No. 11 of 2010 about the Establishment of Disaster Mitigation Body Organization of Bandung Regency and Bandung Regent Decree No. 53 of 2010 about the Details of Task, Function and Organization of Disaster Mitigation Body of Bandung Regency Region, the organization body that responsible for disaster mitigation in Bandung Regency is Regional Disaster Management Agency/ Badan Penanggulangan Bencana Daerah (BPBD) of Bandung Regency (BPBD Kabupaten Bandung 2013).

On the Regional Decree No. 23 of 2013, it is said that the scope of disaster mitigation encompasses 3 (three) stages, which are pre-disaster stage, emergency stage and post-disaster stage. Pre-disaster mitigation covers the effort to create situation that the disaster not to occur and situation that the disaster is detected. Disaster mitigation in emergency stage covers: quick analysis of location, damage and resources; determination of emergency status; rescue 
and evacuation of the victims; fulfillment of basic needs; protection for those who vulnerable; quick recovery of vital infrastructure; and final step implementation of emergency stage. Disaster mitigation covers rehabilitation and reconstruction (Bupati Bandung 2013).

\section{Identification of Flood Disease Potentials by the People of Flood-prone Area}

In identifying disease potentials that may occur because of a flood, the people identify it through: a). Experience, flood disaster and disease that may follow have caused the people to fully understand the disease potential that may occur because of a flood. The informants said that the disease potentials are cough, influenza, respiratory tract infection, itchy and diarrhea. b). Condition identification during a flood, like cold weather causing cough and influenza, bad water condition creating itchy, unhealthy food condition causing fever and diarrhea. According to data from Baleendah health center, the top ten diseases recorded by mobile health center for flood disaster in Baleendah health center operational region on January 2015 are respiratory tract infection, Myalgia, Dermatitis, Gastritis, Hypertension, Conjungtifitis, diarrhea, fever, Paringnitis, etc.

\section{The Ways the People in the Flood-Prone Area Seeking Health Information Solution to Face the Disease Potential Because of a Flood}

According to the FGD and interview results, it can be seen that the people around flood-prone area who become the subject of this research are believe and rely on health information given by healthcare workers, either through doctor or village midwife. Health information provided by healthcare workers is the main information reference for the local people.

Basically, people in areas that become the subject of this research are passive in seeking health information solution. They will ask to the doctor or healthcare workers if they suffer from disease and look for the cure. Health information seeking for prevention or anticipative actions is rarely done. However, the people will be happy to follow the counseling occasion given by the healthcare workers.

Besides physical illness, a flood can also cause psychological problem to the victims. Based on the information obtained from sources from Social Department of Bandung Regency, the agency accompanied by volunteers from Tagana give Post-Disaster PsychoSocial Mitigation Service. Usually disaster victims panic during the disaster, but it rarely makes them stressed. Another example of psychological problems is they cannot stand staying at the evacuation camp for a long time. They are worry with their abandoned possessions. In the said condition, the people usually come to a prominent religious figure and consult about their anxiety particularly related to their lost possessions. The religious figure in this case is the solution to overcome the psychological health problem.

\section{Health Information Sources Used by the People in Flood-Prone Area}

As discussed on the previous section, the main information source regarding health issue in flood-prone area is the healthcare workers. Health information given by healthcare workers is the most trusted information source, according to the opinion of the local people. The information given by the healthcare workers from the health center related to a flood according to the informants is as follows: 1). How to keep healthy, 2). Appropriate diet because when disaster occurs the people get cold so they need foods to keep them from fever, digestive problem, diarrhea, etc. 3). Evacuation to the safer place. 4). Sanitation, 5). The elderly, infants, pregnant women and children should come first, 6). Maintain the cleanliness 
of environment and do not litter. Besides getting information from healthcare workers, some informants who actively involved as a social service cadres use health information sources from health book, TV and brochures as additional sources.

We ourselves found two banners containing health information in front of village office at research subject area. The information contained on the banners is: a). UPTD Health Program of Bojongsoang Health Service Document Year 2015 containing several messages: stop open defecation; hand washing with soap; household drinking water treatment; household garbage treatment and waste water treatment facility, b). Sabilulungan Raksa Desa published by Public Relation of Regional Secretary of Bandung Regency Government. The message contains an abbreviation RAKSA which stands for: $\mathrm{R}=$ Rumah (House), let's together repair the uninhabitable houses; $\mathrm{A}=$ Air (Water), keeping the availability of clean water; $\mathrm{K}=$ Kakus (Toilet), providing the toilet facilities for public use; $S=$ Sampah (Garbage), providing community-based garbage treatment; $\mathrm{A}=$ Alam (Nature), let's plant tree to conserve the nature to create clean and green Bandung.

Such messages contained in the banners cover health information to minimize the result of a flood, like the message which suggesting people to manage their waste. The concern about waste management must be publicized, given that a flood occurred in Bandung is not only because of lower elevation topography, but also the people's behavior littering behavior. With an environment that is clean from waste, it is expected that the flood would not too severe and so does the disease caused by the flood.

\section{Health Information Utilization by the People in Flood-Prone Area}

According to the FGD result, it can be seen that the people obtained health information from healthcare workers regularly on the several events held at the village and neighborhood level. Health information received by the people becomes additional knowledge for them. On the implementation, the people have not fully followed the healthcare workers' suggestion yet. They will ask to the doctor or healthcare workers and follow their suggestions when they get sick to implement the medication.

\section{The Role of Health Institution in Facilitating Health Information Need for the People in Flood-Prone Area}

The health worker in the local health center actively provides health education in the various opportunities, such as in the recitation events, village meetings, meetings of the neighborhood, etc. Provision of information proactively from health workers is in accordance with Ministerial Decree No. 1 of 2013 Item 8th, which reads: The provision of accessibility is a service provided indirectly to the disaster victim and/or the people who live in a disasterprone area whether it is before, during or after the disaster in a form of reference, partnership network, facility and information provision (Minister of Social Affairs Republic of Indonesia 2013).

According to Ministerial Decree No. 1 of 2013 Item $8^{\text {th }}$ above, it can be seen that the provision of information access to the people affected by disasters includes the stages of before (pre) disaster, during disaster and after disaster.

The distribution of authority, task, and function of Satuan Kerja Perangkat Daerah (SKPD/ Regional Apparatus Working Unit) in Disaster Mitigation Execution as discussed on Section II is scribed on the Document of Regent Decree of Bandung Regency No. 23 of 2013 dated May $24^{\text {th }}$, 2013. From this document, it can be seen the role of health institution during the disaster are as follows: a). In pre-disaster phase, where disaster is yet to occur, Majalaya, 
Soreang and Cicalengka Hospital arrange HOPE (Hospital Plan Emergency) and HDP (Hospital Disaster Plan), b). In pre-disaster phase, to reduce disaster risk, Majalaya, Soreang and Cicalengka Hospital carry out socialization and simulation disaster risk eradication in hospital environment, c). In pre-disaster phase, Health Department carries out capacity building training for human resources of health division in disaster mitigation, d). When the disaster potential emerges, for preparation act, Majalaya, Soreang and Cicalengka Hospital prepare temporary evacuation place to anticipate the emergency phase and create patient evacuation track in the hospital, e). In rehabilitation phase, Health Department carries out psychological medication and provides health service, f). In reconstruction phase, Health Department responsible for revitalization of social life by giving counseling for the people.

\section{Public Health Information Behavior in Flood-Prone Area}

As explained on previous section, it can be concluded that the public health information behavior in flood-prone area in Baleendah Village, Andir Village, Dayeuh Kolot Village, and Bojongsoang Village, Bandung Regency is as follows: 1). The people seek health information when they get sick. If they are healthy, they will usually be passive and the ones that actively give the health information to the people are the healthcare workers. 2). The people identify the disease potential during a flood based on their experience and condition during the flood happens. 3). The main and trusted information source by the people of Baleendah Village, Andir Village, Dayeuh Kolot Village and Bojongsoang Village is information obtained from healthcare workers or village midwife. When a flood occurs, the people enthusiastically receive health information from volunteers. 4). Health information use by the people is a lot more for medication process when they get sick. The people do not optimally use the health information they receive for preventive or anticipative action. 5). The health information dissemination from one person to another is almost never conducted because they think that everyone has known. However, some information regarding to children are still disseminated, like information about the prohibition to swim in flood water because it gives rise to skin disease, cough, influenza and fever. Moreover, the parents consider that they children will know by themselves about the flood condition based on their experience.

\section{Conclusion}

According to the research result explained above, it can be concluded that the people around flood-prone area in Baleendah Village, Andir Village, Dayeuh Kolot Village and Bojongsoang Village, Bandung Regency: 1). Identify the disease potential occurred because of a flood based on their experience and observation during a flood. 2). Seek health information solution required to tackle disease potential because of a flood by asking directly to a doctor or a healthcare worker. During a flood, the people also make use of medication post, where there are workers from Health Department or local healthcare or volunteers who can give them health information. For psychological problem, usually the people consult with religious figures, although Social Department has provided them services for this problem. 3). The main information source used by the people is information that is publicized by healthcare worker or village midwife. Besides, in some villages, there are also banners containing health information. The people who come to health center or village office can see it. 4). Make use of health information for medication process when they get sick during disaster. The health information obtained when disaster is yet to come is only for additional knowledge. 5). Health Institution through health center and village midwife proactively provides health counseling on various occasions, such as in recital sessions, village meetings, 
meetings of the neighborhood, etc. Provision of information proactively from health workers is in accordance with Ministerial Decree No. 1 of 2013 Item $8^{\text {th }}$ and its role is scribed on the Document of Regent Decree of Bandung Regency No. 23 of 2013 dated May 24 ${ }^{\text {th }}$, 2013. 6). Public health information behavior in flood-prone area in Baleendah Village, Andir Village, Dayeuh Kolot Village and Bojongsoang Village, Bandung Regency is passive. They will start to seek health information when they get sick. If they are well, the people are usually passive and the healthcare workers are usually active to give health information to the public. The dissemination of health information from a person to another is almost never occurred because they assume that they all already know.

\section{References}

BPBD Kabupaten Bandung. (2013). tugas pokok dan fungsi BPBD. Retrieved from http://www.bandungkab.go.id/public/uploads/TUGAS_POKOK_DAN_FUNGSI_BP BD.pdf

BPBD Kabupaten Bandung. (2013). Visi misi Badan Penanggulangan Bencana Daerah. Retrieved from http://www.bandungkab.go.id/arsip/3005/visi-dan-misibpbd\#sthash.i6VZsZAo.dpuf

Budiana, O. R. (2011). Ini dia daerah rawan bencana di Kota Bandung. Retrieved May 1, 2015, from http://news.detik.com/read/2011/05/25/230009/1647210/486/1/ini-diadaerah-rawan-bencana-di-kota-bandung

Bupati Bandung. (2013). Peraturan Bupati Kabupaten Bandung No. 2 Tahun 2013. penyelenggaraan penanggulangan bencana di Kabupaten Bandung. Soreang: Pemda Kabupaten Bandung.

Bupati Bandung. (2013). Peraturan Bupati Kabupaten Bandung Nomor 23 Tahun 2013. pembagian kewenangan, tugas, dan fungsi satuan kerja perangkat daerah dalam penyelengaraan penanggulangan bencana Di Kabupaten Bandung. Soreang: Pemda Kabupaten Bandung.

Bupati Kabupaten Bandung. (2013). Peraturan Bupati Kabupaten Bandung Nomor 12 Tahun 2013. partisipasi masyarakat dan keterbukaan informasi publik dalam penyelenggaraan pemerintah di Kabupaten Bandung. Soreang: Pemda Kabupaten Bandung.

Lin, Y. H., Chen, R. R., \& Chang, H. K. (2012). Analysing information behaviour in structured service encounters: a case of call centre operations. IR Information Research, 17(2), 517.

Menteri Sosial Republik Indonesia. (2013). Permen No.1 Tahun 2013. bantuan sosial bagi korban bencana Jakarta: Departemen Sosial. Retrieved from http://www.kemenpppa.go.id/jdih/peraturan/nspk-permensos-01-2013-bantuan-sosialkorban-bencana.pdf

MP, I. (2014). Secara geologis, Bandung daerah rawan banjir. Retrieved from http://www.tempo.co/read/news/2014/12/27/058631261/Secara-Geologis-BandungDaerah-Rawan-Banjir

Presiden RI. (2014). PP No.46 Tahun 2014 tentang sistem informasi kesehatan. Jakarta: RI.

Sonnenwald, D. H., \& Wildemuth, B. M. (2001). Investigating information seeking behavior using the concept of information horizons. NC: University of North Carolina.

Susanti, R. (2014). Enam penyakit serang korban banjir Bandung Selatan. Retrieved from http://regional.kompas.com/read/2014/12/25/09112811/Enam.Penyakit.Serang.Korba n.Banjir.Bandung.Selatan 
Wilson, T. (1996). Information behaviour, an interdisciplinary perspective. Retrieved, from http://www.informationr.net/tdw/publ/infbehav/chap2.html

Wilson, T. (2000). Human informastion behaviour. Retrieved from http://inform.nu/Articles/Vol3/v3n2p49-56.pdf 